Journal of Extension Education

Vol. 28 No. 1, 2016

\title{
Entrepreneurship Motivation of Fisheries Graduates : An Exploratory Study
}

\author{
M. Kumaran ${ }^{1}$ and PR. Anand ${ }^{2}$
}

\begin{abstract}
Farm graduates need to be entrepreneurial to excel in their chosen career. The present study conducted among the outgoing fisheries graduates showed that their entrepreneurship motivation levels (70-80\%) are moderate with poor risk taking (72\%), inadequate locus of control (74\%) and low self-efficacy (79\%) propensities. It is learnt that entrepreneurship and personality development content in fisheries curriculum is inadequate. Therefore, it is suggested that the course curriculum should incorporate entrepreneurship and personality development as a course with adequate practical exposure to enhance their capacity and attitudinal predisposition.
\end{abstract}

Keywords : Fisheries, entrepreneurship motivation, personality development.

\section{INTRODUCTION}

Fisheries and aquaculture constitute about $1 \%$ of the national GDP and 5.08 per cent of agriculture GDP. The total fish production during 2014-15 was 10.16 MT and export revenue of R.30000 crores was realized from fisheries (Economic Survey, GOI, 2015-16). Aquaculture of fishes contributed $60 \%$ of the production and the remaining 40\% was from the capture fisheries. Since the production from capture fisheries from the natural waters has been plateaued over the recent years, aquaculture is the only option for enhancing fish production to meet the increasing demand for food fish. The percapita fish consumption in India is about $10 \mathrm{~kg} /$ year as against the global average of $20 \mathrm{~kg} /$ year. The increasing trend in fish consumption is mainly due to the growing awareness of fish as health food among the public. Presently we utilize 50\% and $15 \%$ of fresh and brackish water potential respectively for farming and the productivity of our aquaculture systems are far below than the global average. Aquaculture of fish and shrimps require both scientific capacity and business skills, hence need entrepreneurship. Therefore, inflow of fisheries graduates in to aquaculture and allied ventures is important for the sustainable development and augmenting

1 - Principal Scientist and 2 - Research Scholar, ICAR-Central Institute of Brackishwater Aquaculture, Chennai-600 028. 
the fisheries production.

Entrepreneurship development in agrarian sector is regarded as one of the major requirement and developing entrepreneurial potential among the farm graduates has been attracting the interest of policy makers, educationalists and development agencies in recent years. Indeed, entrepreneurial education is a tool for eradicating graduate unemployment and there is evidence that promoting entrepreneurship can solve the problem of unemployment. Yet, unemployment thrives among young agriculture and allied graduates. Entrepreneurship enhances the individual and collective capacity of rural youth to implement sustainable rural enterprises.

The existing gap between the skills required by the employers and the profile of the graduates has been reported as a reason for unemployment. Entrepreneurial education programmes are sources of entrepreneurial attitude and overall intentions to become future entrepreneur. Lack of focused entrepreneurialeducationleads tolowlevel of entrepreneurial intentions of students. The relevance of the curriculum to the job is an important factor that could also determine employability(Laraya; 2009). The empirical results in entrepreneurship confirm the relationship between attitudes and self-employment. Self-employment experience was directly related with entrepreneurial intentions of students
(Raijman, 2001). Curriculum content is instrumental to the development of competencies and skills and acquiring the same by a graduate is influenced by the demand and supply relationship of the employee and the employers/ industries. Yet, there is a dearth of research into youth entrepreneurship in the agrarian context. In this context, the present study was taken up to explore the entrepreneurship motivation levels of outgoing fisheries graduates.

\section{METHODOLOGY}

Several studies measured entrepreneurship motivation among the graduates in the form of human behaviour by assessing their personality traits. Numerous studies assessed entrepreneurial behaviour by measuring the traits viz., achievement motivation internal locus of control, risk taking propensity intolerance to ambiguity, innovativeness information seeking behaviour and self-efficacy either individually or in different combinations. In the present study, similar approach was adopted. The traits selected and their relative weightage are, need for achievement (NA-2.1); locus of control (LC- 1.2); risk taking ability (RT1.8); tolerance for ambiguity (TA-1.2); innovativeness (I-1.4); self-efficacy (SE1.2) and information seeking behaviour (ISB-1.1). Thirty statements reflecting these traits were selected and a summated rating procedure was constructed as 
suggested by Likert (1932) and Edward (1957) to measure the entrepreneurship behaviour of the respondents. An Entrepreneurship Motivation Index was calculated as the ratio of Individual's obtained score $\left(\sum \mathrm{NA} * 2.1+\mathrm{LC} * 1.2+\mathrm{RT} *\right.$ $\left.1.8+\mathrm{TA}^{*} 1.2+\mathrm{I}^{*} 1.4+\mathrm{SE}^{*} 1.2+\mathrm{ISB}^{*} 1.1\right) \quad$ to the maximum possible score (181).

Further, socio-personal variables viz., gender, first graduate in family, percentage of marks, nativity, type of family, family size, earning members, fathers occupation, parents educational status, family annual income, community, preferred employment, participation in training, interaction with entrepreneurs and mass media contact were also studied adopting suitable scoring procedures to understand the socio-personal profile of respondents and interpret the results meaningfully. A sample size of 60 outgoing fisheries graduates from two fisheries colleges was selected for the study and the primary data from the respondents were collected through a questionnaire. Descriptive statistics and linear regression analysis aided in summarizing the results and delineating the influence of personal profile variables on the entrepreneurship motivation behaviour of the respondents.

\section{FINDINGS AND DISCUSSION}

\section{Socio- Personal Profile of Respondents}

Socio-personal characteristics of the respondents were studied to have an idea about the demographic background of the respondents. Majority of the respondents (63\%) were female and it shows that women are interested in fisheries subject and scope for employment in fisheries is relatively high. Half of the respondents (52\%) were the first graduates in their family which is indicating that the respondents were representing middle and lower strata of the society. Around $60 \%$ of their parents were educated in the range of middle to high school level and having understood the value of education, hence the parents wanted their wards to become graduates. As majority of the respondents (63\%) hailed from rural background and studied in mother tongue hardly one fourth $(27 \%)$ of them had scored more than $80 \%$ in their overall percentage of marks. Nearly three fourths (72\%) of them were from nuclear families with small family size (68\%) and single earning households $(72 \%)$. Family occupation of one third of respondents (33\%) was agriculture, 20\% belonged to a small-scale business family and about half the respondents' (47\%) parents were working as employee either in a government department or private companies. Nearly half of the respondents (48\%) expressed that their family annual income was less than Rs.10,000 per month and $38 \%$ of their family with an annual income range of Rs. 1 to 3 lakhs. One third of the respondents (33\%) were from SC/ST community and half of the 
respondents (52\%) hailed from backward communities. Majority of them (78\%) preferred to go for employment rather than seeking self-employment. Majority of them $(62 \%)$ had better mass media exposure in the form of browsing internet and reading newspapers regularly. Half of the respondents (50\%) had interacted with entrepreneurs in fisheries and aquaculture sector during their rural

Table-1. Socio-Personal Profile of the Respondents

\begin{tabular}{|c|c|c|}
\hline S1.No. & $\begin{array}{c}\text { Profile } \\
\text { characteristics }\end{array}$ & $\%$ of Respondents \\
\hline \multirow[t]{3}{*}{1.} & \multicolumn{2}{|l|}{ Gender } \\
\hline & Male & 36.67 \\
\hline & Female & 63.33 \\
\hline \multirow[t]{3}{*}{2.} & \multicolumn{2}{|l|}{ First Graduate in Family } \\
\hline & Yes & 51.67 \\
\hline & No & 48.33 \\
\hline \multirow[t]{4}{*}{3.} & \multicolumn{2}{|l|}{ Overall Percentage of Marks } \\
\hline & $<70 \%$ & 35.00 \\
\hline & $71-80$ & 38.33 \\
\hline & 81 and above & 26.67 \\
\hline \multirow[t]{3}{*}{4.} & Nativity & \\
\hline & Rural & 63.33 \\
\hline & Urban & 46.67 \\
\hline \multirow[t]{3}{*}{5.} & Type of Family & \\
\hline & Nuclear & 71.67 \\
\hline & Joint/Extended & 28.33 \\
\hline \multirow[t]{3}{*}{6.} & Family Size & \\
\hline & Up to 4 members & 68.33 \\
\hline & $5 \&$ above & 31.67 \\
\hline \multirow[t]{3}{*}{7.} & Earning members & \\
\hline & Single earner & 71.67 \\
\hline & More than one earner & 28.33 \\
\hline \multirow[t]{4}{*}{8.} & Fathers' Occupation & \\
\hline & Agriculture & 33.33 \\
\hline & Business & 20.00 \\
\hline & Employee (Govt/Pvt) & 46.67 \\
\hline
\end{tabular}


$(n=60)$

\begin{tabular}{|c|c|c|}
\hline S1.No. & $\begin{array}{c}\text { Profile } \\
\text { Characteristics }\end{array}$ & $\begin{array}{l}\text { \% of Respondents } \\
\qquad(\mathrm{N}=60)\end{array}$ \\
\hline 9. & \multicolumn{2}{|l|}{ Parents' Education Status } \\
\hline & Illiterate & 10.00 \\
\hline & Primary education & 13.33 \\
\hline & Middle School & 36.67 \\
\hline & SSLC/HSC & 21.67 \\
\hline & Graduate $\&$ above & 18.33 \\
\hline \multirow[t]{4}{*}{10.} & \multicolumn{2}{|l|}{ Family Annual Income } \\
\hline & $<1$ lakh & 48.33 \\
\hline & 1-3 lakh & 38.33 \\
\hline & $>3$ lakh & 13.33 \\
\hline \multirow[t]{5}{*}{11.} & \multicolumn{2}{|l|}{ Community } \\
\hline & $\mathrm{SC} / \mathrm{ST}$ & 33.33 \\
\hline & MBC & 11.67 \\
\hline & $\mathrm{BC}$ & 40.00 \\
\hline & $\mathrm{FC}$ & 15.00 \\
\hline \multirow[t]{3}{*}{12.} & Preferred Employment & \\
\hline & Self employment & 21.67 \\
\hline & Govt./Private job & 78.33 \\
\hline \multirow[t]{3}{*}{13.} & \multicolumn{2}{|l|}{ Participation in Training } \\
\hline & Attended & 40.00 \\
\hline & Not attended & 60.00 \\
\hline \multirow[t]{3}{*}{14.} & \multicolumn{2}{|l|}{ Interaction with Entrepreneurs } \\
\hline & Yes & 50.00 \\
\hline & No & 50.00 \\
\hline \multirow[t]{3}{*}{15.} & \multicolumn{2}{|l|}{ Mass Media Exposure } \\
\hline & Yes & 61.67 \\
\hline & No & 38.33 \\
\hline
\end{tabular}

on employment opportunities in fisheries sector. Jyothi et al, (2009) reported similar work experience programmes and $40 \%$ of them attended a training or workshop socio-economic background in case of outgoing agricultural graduates.

\section{Entrepreneurship Motivation of Respondents}

Entrepreneurship motivation behaviour of respondents assessed through their personality traits is presented in the Figures - 18\%2. About 
half of the respondents (53\%) exhibited moderate entrepreneurship motivation and $30 \%$ of them had shown higher level of entrepreneurship motivation behaviour. Moderate level of entrepreneurship motivation is mainly due to their preference for job employment because of their poor economic background. The graduate students preferred to be managers rather than entrepreneurs. This fact is clearly evident in their low level of risk taking behaviour and their perception that success is not in their hands (Fig-2). However, this behaviour needs to be corrected through entrepreneurship and personality development training programmes which should focus on changes in attitude towards selfemployment, develop entrepreneurial ability, and enhance self-confidence which in turn, will promote successful agribusiness ventures as reported by Parimaladevi et al, (2006). Pajares (2002) also emphasized that unless people believe that their actions can produce the outcomes they desire, they have little incentive to act or to persevere. Mirzaei et al, (2007) reported similar findings stating that demographic determinants and position in society compels graduate students seek employment in governmental and private organizations. Lack of entrepreneurial education leads to low level of entrepreneurial intentions of students Contents of entrepreneurship education would have a positive impact on perception of students about entrepreneurial education. In this regard, a sound educational program is a necessary prerequisite for enhancing the capacity of students to start entrepreneurship activity (Hosseini et al, 2011). Therefore, the entrepreneurship education provided as part of the

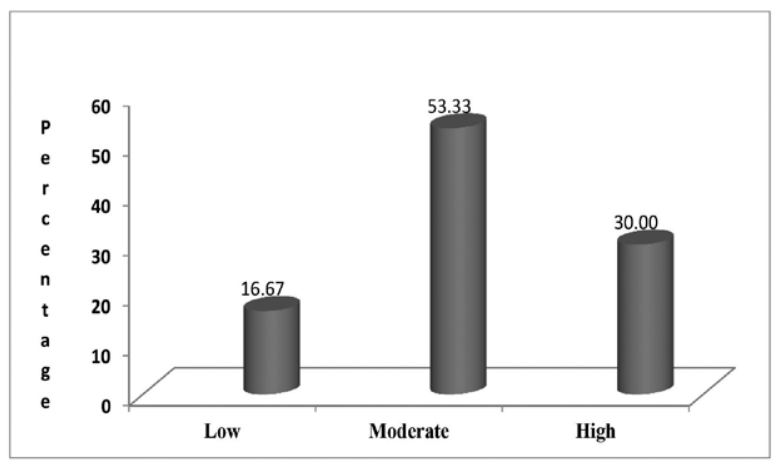

Fig 1. Entrepreneurship Motivation of Fisheries Graduates

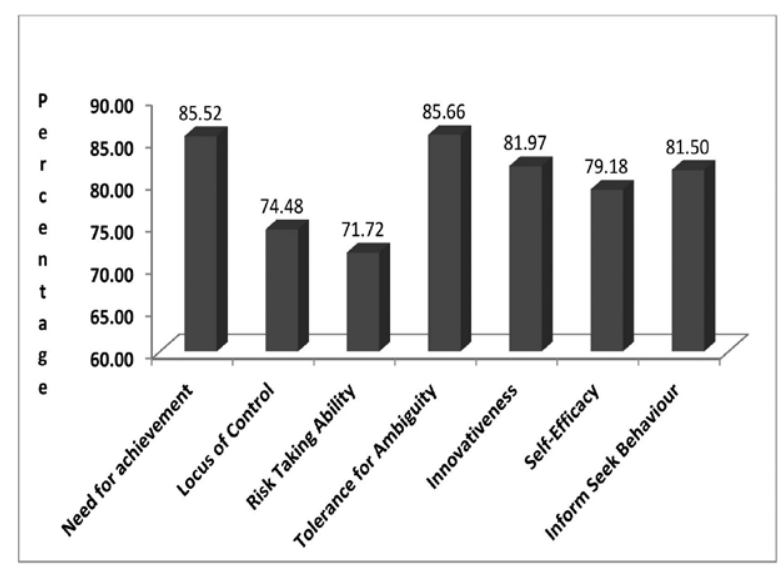

Fig 2. Entrepreneurial Traits of Fisheries Graduates

graduate curriculum needs reorientation with adequate exposure to business units, interaction with entrepreneurs and schemes available for entrepreneurship development in fisheries sector.The rural 
work experience programme can be also fine-tuned to attach potential students with relevant enterprises may go a long way in developing entrepreneurship motivation and calculated risk taking predisposition.

\section{Level of Influence of Socio-Personal Profile on Entrepreneurship Motivation}

Studies found that socio-personal characteristics had an impact on entrepreneurial intention and endeavour, personal qualities and traits Mirzaei et al., 2007). In the present study the linear regression analysis showed that $58 \%$ of changes in the entrepreneurial motivation behaviour of the respondents are explainable by the socio-personal variables $(\mathrm{R} 2=0.584)$. Table- 2 shows that out of 15 socio-personal variables included for the analysis three variables viz., educational background of the parents, community and mass media contact were found to be significantly influencing the entrepreneurial behaviour of outgoing graduates. Community was found to influence the behaviour of the individual at $1 \%$ level of probability. It may be understood that $52 \%$ of the respondents hailed from backward and most backward classes and one third from scheduled castes. Studies indicated that family business background characteristics had an impact on

Table-2. Influence of Socio-Personal Characteristics on Entrepreneurship Behaviour

\begin{tabular}{|c|l|r|}
\hline S1.No. & \multicolumn{1}{|c|}{ Profile Characteristics } & \multicolumn{2}{|c|}{$\begin{array}{c}\text { Regression } \\
\text { Co-efficient }\end{array}$} \\
\hline 1. & Gender & -1.061 \\
\hline 2. & First Graduate & .585 \\
\hline 3. & Academic marks percent & -.064 \\
\hline 4. & Nativity & -.804 \\
\hline 5. & Family type & -1.417 \\
\hline 6. & Family size & -.109 \\
\hline 7. & Family Earning status & -.019 \\
\hline 8. & Parent Occupation & -.229 \\
\hline 9. & Parent Education & $1.958^{*}$ \\
\hline 10. & Family Annual Income & 1.190 \\
\hline 11. & Community & $2.881^{* *}$ \\
\hline 12. & Job preference & -.447 \\
\hline 13. & Training attended & .347 \\
\hline 14. & Interaction with entrepreneur & .107 \\
\hline 15. & Mass Media contact & $2.341^{*}$ \\
\hline & & \\
\hline
\end{tabular}

** Significant at $1 \%$ level \& * $5 \%$ level of probability 
entrepreneurial intention (Aldrich and Cliff, 2003; Carr and Sequeira 2007). However, Adsul et al. (2008) reported that caste, gender and economic background of family do not affect the achievement motivation of college students. But Mirakzadeh and Ghiasy (2011) reported that socio- economic context determine the employability of agricultural graduates. Mass media contact was significantly influencing the entrepreneurship motivation behaviour at $5 \%$ level of probability. Mass media also play an important role in influencing the entrepreneurship phenomenon. Earlier studies indicated that entrepreneurial behaviour was positively and significantly related to mass media exposure (Rautand Gopal Sankhala, 2014; Sreeram et al., 2015).

\section{CONCLUSION}

The study found that outgoing fisheries graduates had moderate level of entrepreneurship motivation, low level of risk taking, self-efficacy and locus of control. Most of them preferred jobs rather than self-employment. Nevertheless, they need to have confidence, positive attitude, proficiency in subject and entrepreneurial qualities to excel in their chosen career. Therefore, it is important that a course on entrepreneurship and personality improvement need to be incorporated in to the fisheries course curriculum. Adequate practical exposure to successful business units and enhanced interactions with career counsellors, entrepreneurs in the field of fisheries and aquaculture might help the students to decide their career. Further, personality development workshops need to be incorporated in the fisheries practical to improve or hone the personal traits and attitude of outgoing students so that they could confidently face the real world.

\section{REFERENCES}

Adsul, R. K., Kamble, V. \& Sangli, K. W. (2008). Achievement Motivation as a Function of Gender, Economic Background and Caste Differences in College Students. Journal of the Indian Academy of Applied Psychology, 34, 323-327.

Aldrich. H. E \& Cliff J.E. (2003). The Pervasive Effects of Family on Entrepreneurship: Toward a Family Embeddedness Perspective, Journal of Business Venturing, 18 (5),573-596.

Carr. J. C \& Sequeira, J. M. (2007). Prior Family Business Exposure as Intergenerational Influence and Entrepreneurial Intent: A Theory of Planned Behavior Approach, Journal of Business Research, 60, 1090-1098.

Hosseini, S. J. F, H. Ahmadi \& Najafabadi, M.O. (2011). The Perceptions of Graduate Students about Factors Influencing the Extension of Entrepreneurship Education in College of Agriculture and Natural 
Resources in Iran, Journal of American Science, 7(3), 255-259.

Jyothi,V., Ananda rao, V., Vijayabhinandana, B \& Sunil, N. K. (2009). Profile Characteristics of Undergraduate and Postgraduate Students in Acharya N. G. Ranga Agricultural University, Karnataka Journal of Agricultural Sciences, 22 (5), 1146-1147

Mirakzadeh. A.A \& Ghiasy.F.G. (2011). Effective Factors on the Employment Status of Agricultural Graduates in Iran, African Journal of Agricultural Research 6(2), 432-439.18 January, 2011

Mirzaei, R., Shamekhi, T., Naeli, M.A, Zahedi, G. \& Jazireei, M. (2007). The
Relation Between Higher Education and Efficiency and Occupation of Graduates; View of University Professors, Administrators and Graduates: A Case Study in Forestry Higher Education. Research Reform National Resources., 73, 11-26.

Pajares, F. (2002). Overview of Social Cognitive Theory and Self-efficacy, [Online] Available: http://www.emory. edu/EDUCATION/mfp/eff.html

Parimaladevi, S., Sakeer Husain. A. \& Bhaskaran, S. (2006). Determinants of the Effectiveness of Agriclinics and Agribusiness Centres Scheme' in Kerala, Journal of Tropical Agriculture, 44 (1-2), 91-93, 